\title{
KEBIASAAN JAJAN SISWA SEKOLAH DASAR (Studi Kasus di SDN Lawanggintung 01 Kota Bogor)
}

\author{
(Snacking Habits Among Elementary School Student, Case Study in \\ SDN Lawanggintung 01 Kota Bogor)
}

\author{
Yunita Syafitri ${ }^{1}$, Hidayat Syarief ${ }^{1}$, dan Yayuk Farida Baliwati ${ }^{1^{*}}$
}

\begin{abstract}
${ }^{1}$ Departemen Gizi Masyarakat, Fakultas Ekologi Manusia, Institut Pertanian Bogor, Bogor 16680 ${ }^{1}$ Departemen Gizi Masyarakat, Fakultas Ekologi Manusia, Institut Pertanian Bogor, Bogor 16680 ${ }^{1 *}$ Alamat Korespondensi: Departemen Gizi Masyarakat, Fakultas Ekologi Manusia, Institut Pertanian Bogor, Bogor 16680. Telp: 0251-8621258; Fax: 0251-8622276; E-mail: yayuk_gm@yahoo.com
\end{abstract}

\begin{abstract}
Healthy foods contribute to elementary school student proper growth and development. During school time they have greater access and sufficient opportunity to consume street food that available at school. However, poor street food choices can result in unbalance diet. Availability of street food in school play significant role to elementary school student diet. Street food can contribute 10-20\% nutrients toward student daily consumptions. Street food devide into main dishes, snacks, and beverages. The aim of this study was to assess snacking habit of elementary school student in SDN Lawanggintung 01 Kota Bogor. Snacking habits devined as number of street food type and frequency of snacking in school area included canteen merchants and outside school permanent merchants. Design of this study was cross sectional. Fifty student were selected using simple random sampling. Street food contributed to $26.0 \%$ energy; $18.7 \%$ protein; $22.9 \%$ lipid, $20.0 \%$ iron; $19.1 \%$ vitamin A; dan $24.8 \%$ vitamin C to total daily intake. Street food had contribute to $23.0 \%$ energy; $21.7 \%$ protein; $30.9 \%$ lipid, $19.5 \%$ iron; $24.1 \%$ vitamin $A$; dan $26.6 \%$ vitamin $C$ to adequate intake level. Age and gender had not related to street food habits. Pocket money to purchased food is related to street food habits. Childrens familiy social economic characteristic not related to street food habits. Pocket money to purchased food affected street food habits.
\end{abstract}

Keyword: snacking habits, street food, elmentary school student.

\section{PENDAHULUAN}

\section{Latar Belakang}

Makanan jajanan merupakan bagian tidak terpisahkan dari kehidupan anak sekolah dasar. Konsumsi dan kebiasaan jajan anak turut mempengaruhi kontribusi dan kecukupan energi dan zat gizinya yang berujung pada status gizi anak. Suhardjo (1989) menyebutkan bahwa kebiasaan jajan merupakan istilah untuk menggambarkan kebiasaan dan prilaku yang berhubungan dengan makan dan makanan seperti frekuensi makan, jenis makanan, kepercayaan terhadap makanan (pantangan), preferensi terhadap makanan, dan cara pemilihan makanan.

Penelitian Ulya (2003) yang dilakukan pada salah satu sekolah dasar di Jakarta Timur menyebutkan bahwa kontribusi makanan jajanan terhadap konsumsi sehari siswa berkisar antara 10-20\%. Energi dari makanan jajanan memberikan kontribusi sebesar $17.36 \%$, protein sebesar $12.4 \%$, karbohidrat sebesar $15.1 \%$, dan lemak sebesar $21.1 \%$ terhadap konsumsi sehari.

Semakin beragamnya jenis makanan jajanan yang menarik dan ditawarkan dengan harga yang murah di sekolah menuntut siswa SD untuk lebih selektif dalam memilih makanan. Kajian yang membahas tentang kebiasaan jajan pada siswa SD, faktor-faktor yang berhubungan dan berpengaruh masih sedikit dan kurang mendalam. Mengingat peran strategis makanan jajanan terhadap pemenuhan energi dan zat gizi, serta pertumbuhan siswa SD, maka penting untuk mengetahui kebiasaan jajan serta faktorfaktor yang berhubungan dan berpengaruh.

Tujuan

Penelitian ini secara umum bertujuan untuk mengetahui kebiasaan jajan siswa sekolah dasar di SDN Lawanggintung 01 Kota Bogor. Adapun tujuan khususnya adalah 1) mengidentifikasi karakteristik siswa dan pengetahuan gizi siswa tentang makanan jajanan serta karakteristik sosial ekonomi 
keluarga siswa siswa; 2) mengidentifikasi ketersediaan makanan jajanan di sekolah; 3) mengidentifikasi kebiasaan jajan siswa; 4) menganalisis kontribusi makanan jajanan terhadap konsumsi sehari dan kecukupan energi dan zat gizi siswa; 5) menganalisis hubungan karakteristik siswa, pengetahuan gizi siswa tentang makanan jajanan, dan karakteristik keluarga dengan kebiasaan jajan siswa; dan 6) Menganalisis faktor-faktor yang berpengaruh terhadap kebiasaan jajan siswa.

\section{METODE}

\section{Desain, Tempat, dan Waktu Penelitian}

Desain yang digunakan dalam penelitian ini adalah cross sectional, bertempat di SDN Lawanggintung 01 Kota Bogor. Penelitian ini merupakan baseline pada kajian "Pengembangan Model Pendidikan Makanan jajanan Sehat Berbasis Sekolah untuk Tingkat Sekolah Dasar" yang dilakukan oleh Southeast Asian Food and Agricultural Science and Technology (SEAFAST) Center dan Lembaga Penelitian dan Pengabdian Kepada Masyarakat (LPPM) Institut Pertanian Bogor. Penelitian dilaksanakan pada bulan Mei sampai Juli 2009. Penentuan lokasi SDN Lawanggintung 01 Kota Bogor pada penelitian ini diambil secara purposive dengan persyaratan sebagai berikut: 1) mendapatkan rekomendasi dari kantor dinas pendidikan setempat, 2) komitmen dari pihak sekolah, dan 3) mempunyai kantin sekolah.

\section{Jumlah dan Cara Penarikan Contoh}

Contoh dalam penelitian ini adalah siswa sekolah dasar kelas IV dan V SDN Lawanggintung 01 Kota Bogor yang termasuk kategori kelas tinggi. Anak pada masa kelas tinggi memiliki kemampuan konkritoperasional yang mampu untuk berpikir secara sistematik terhadap objek konkrit. Anak sudah bisa mengambil kesimpulan dari suatu pertanyaan (Harlock 1997). Siswa berjumlah 50 orang yang diambil secara acak sederhana (simple random sampling).

\section{Jumlah dan Cara Pengumpulan Data}

Data yang dikumpulkan meliputi data primer dan data sekunder. Pengambilan data primer dilakukan melalui wawancara langsung menggunakan kuesioner. Jenis data primer yang dikumpulkan antara lain karakteristik siswa (umur, jenis kelamin, dan besar uang saku), pengetahuan gizi tentang makanan jajanan siswa, kebiasaan jajan siswa (frekuensi jajan dan jumlah jenis makanan jajanan), konsumsi pangan siswa (recall 2×24 jam), dan karakteristik sosial ekonomi keluarga (pendidikan orang tua, pekerjaan orang tua, pendapatan keluarga, dan besar keluarga). Data sekunder berupa profil sekolah.

\section{Pengolahan dan Analisis Data}

Proses pengolahan data meliputi editing, coding, entry, dan analisis data. Analisis data menggunakan Microsoft Excel dan SPSS 14.0 for Windows.. Analisis hubungan menggunakan korelasi Spearman dan Pearson. Analisis pengaruh menggunakan regresi linear berganda dengan persamaan:

Persamaan regresi yang digunakan :

$Y=a+B 1 X 1+\ldots .+B n X n+e$

Ket :

$\mathrm{Y}=$ Variabel dependen

$\alpha=$ Konstanta, angka konstan koefisien regresi

$B 1, \ldots, B n=$ Koefisien variabel independen

$\mathrm{X} 1, \ldots, \mathrm{Xn}=$ Variabel independen

\section{HASIL DAN PEMBAHASAN}

\section{Gambaran Umum Lokasi}

Sekolah Dasar Negeri (SDN) Lawanggintung 01 didirikan pada tahun 1966 memiliki akreditasi A. Terletak di Jalan Lawang Gintung No. 22 Kecamatan Bogor Selatan, Kota Bogor, Provinsi Jawa Barat.

Peraturan sekolah yang berkaitan dengan makanan jajanan ditekankan pada pemeliharaan kebersihan di tempat berjualan. Peraturan hanya bersifat lisan dan belum ada sanksi yang jelas bila terjadi pelanggaran.

\section{Karakteristik Siswa \\ Umur dan Jenis Kelamin}

Umur siswa berkisar antara 9-12 tahun. Sebagian besar siswa berumur 10 tahun, yakni sebanyak $55.6 \%$ laki-laki dan (56.5\%) perempuan.

\section{Besar Uang Saku dan Alokasinya}

Besar uang saku siswa berkisar antara Rp 3.000 - Rp 14.000. Sebagian besar (88.0\%) siswa menerima uang saku antara Rp 2.800 Rp 7.000. Uang saku yang diberikan orang tua setiap hari, oleh siswa dialokasikan kembali sesuai dengan keperluannya. Lebih dari separuh siswa mengalokasikan uang sakunya untuk keperluan membeli makanan jajanan (68\%). Hanya $8 \%$ siswa yang mengalokasikan uang sakunya untuk keperluan transportasi. Sebesar $12 \%$ siswa mengalokasikan uang sakunya untuk menabung. 
Pengetahuan Gizi tentang Makanan jajanan

Pengetahuan gizi merupakan aspek kognitif yang menunjukan pemahaman responden tentang ilmu gizi, jenis zat gizi, serta interaksinya terhadap status gizi dan kesehatan. Pengetahuan gizi merupakan landasan yang penting dalam menentukan konsumsi makanan (Khomsan 2000). Sebanyak 44.0\% siswa memiliki pengetahuan gizi tentang makanan jajanan sedang. Sepertiga (32.0\%) siswa memiliki pengetahuan gizi kurang. Sekitar seperlima (24.0\%) siswa yang memiliki pengetahuan gizi baik. Rata-rata siswa memiliki pengetahuan gizi sedang. Beragamnya tingkat pengetahuan gizi tentang makanan jajanan siswa dapat disebabkan oleh beberapa hal, salah satunya beragamnya sumber informasi gizi yang diterima siswa. Sumber infomasi mengenai pengetahuan gizi diantaranya bearasal dari orang tua, sekolah, serta media cetak dan elektronik. Pengetahuan gizi pada tingkat sekolah dasar diantaranya terdapat dalam mata pelajaran ilmu pengetahuan alam dan pendidikan jasmani dan kesehatan.

\section{Karakteristik Keluarga Pendidikan Orang Tua}

Pendidikan orang tua siswa sebagian besar adalah SMA (ayah sebanyak $72.0 \%$ dan ibu sebanyak 58.0\%). Hanya dua orang ayah dan ibu siswa yang merupakan tamatan SD. Hal ini menunjukkan bahwa tingkat pendidikan orang tua siswa tergolong sedang.

\section{Pekerjaan Orang Tua}

Sebanyak $36.0 \%$ ayah siswa bekerja sebagai di sektor swasta dan $32.0 \%$ ayah siswa bekerja sebagai TNI/POLRI. Sebagian besar ibu (62.0\%) ibu siswa adalah sebagai ibu rumah tangga.

\section{Pendapatan Keluarga}

Pendapatan keluarga merupakan pendapatan keluarga yang diterima setiap bulan dibagi dengan jumlah anggota keluarga. Pendapatan keluarga siswa seluruhnya tergolong tidak miskin. Rata-rata pendapatan
Rp. 716.866.67 \pm Rp. 609.197.8. Berdasarkan pendapatan keluarga, tingkat ekonomi keluarga siswa tergolong mengengah ke atas.

\section{Besar Keluarga}

Jumlah anggota keluarga siswa berkisar antara 3-8 orang kemudian dikelompokkan menjadi tiga yaitu keluarga kecil ( $\leq 4$ orang), sedang (5-7 orang), dan besar ( $\geq 8$ orang). Lebih dari separuh (66\%) keluarga siswa termasuk dalam kategori keluarga kecil.

\section{Ketersediaan Makanan Jajanan di Sekolah}

Terdapat 95 jenis makanan jajanan yang dijual di lingkungan sekolah. Makanan jajanan yang paling banyak dijual adalah makanan camilan/panganan (47 jenis), yang kedua adlah minuman (30 jenis), dan sisanya sebanyak 18 jenis merupakan makanan utama/sepinggan. Sebagian besar makanan jajanan (77.8\%) tersedia di kantin sekolah dan hanya $22.2 \%$ yang tersedia di luar sekolah (penjaja menetap) (Tabel 1).

Makanan jajanan kelompok makanan utama/sepinggan yang tersedia sebagian besar (72.2\%) merupakan makanan jajanan tradisional, hanya $27.8 \%$ yang berupa makanan pabrikan. Makanan utama/sepinggan tradisional yang dijual diantaranya bubur ayam, kwetiau, nasi goreng, mie ayam, dan lainnya. Makanan utama/sepinggan yang merupakan makanan pabrikan seluruhnya tersedia dalam bentuk mie instant. Makanan jajanan kelompok makanan camilan/ panganan sebagian besar (76.6\%) merupakan makanan pabrikan.

Dijual diantaranya aneka produk ekstruksi, keripik, biskuit, coklat, permen, kacang, serta produk hasil olahan daging dan ikan. Makanan jajanan kelompok minuman sebagian besar minuman (73.3\%) merupakan minuman pabrikan. Minuman pabrikan yang tersedia dalam bentuk minuman serbuk, air kemasan beraroma, minuman berkarbonasi, minuman jelly, serta susu dan produk olahannya. Minuman tradisional yang tersedia diantaranya adalah jus buah dan aneka minuman es. 
Tabel 1. Sebaran Ketersediaan Makanan Jajanan Berdasarkan Tempat Beli, Produsen, dan Bahan Baku

\begin{tabular}{|c|c|c|c|c|c|c|c|c|}
\hline \multirow{2}{*}{ Jenis jajanan } & \multicolumn{2}{|c|}{$\begin{array}{c}\text { Makanan } \\
\text { utama/sepinggan }\end{array}$} & \multicolumn{2}{|c|}{$\begin{array}{c}\text { Makanan } \\
\text { camilan/panganan }\end{array}$} & \multicolumn{2}{|c|}{ Minuman } & \multicolumn{2}{|c|}{ Total } \\
\hline & $\mathrm{n}$ & $\%$ & $\mathrm{n}$ & $\%$ & $\mathrm{n}$ & $\%$ & $\mathrm{n}$ & $\%$ \\
\hline \multicolumn{9}{|c|}{ Tempat beli } \\
\hline Kantin & 14 & 77.8 & 39 & 83.0 & 22 & 73.3 & 75 & 78.9 \\
\hline Luar sekolah & 4 & 22.2 & 8 & 17.0 & 8 & 26.7 & 20 & 21.1 \\
\hline Total & 18 & 100.0 & 47 & 100.0 & 30 & 100.0 & 95 & 100.0 \\
\hline \multicolumn{9}{|c|}{ Produsen } \\
\hline Pabrikan & 5 & 27.8 & 36 & 76.6 & 22 & 73.3 & 63 & 66.3 \\
\hline Tradisional & 13 & 72.2 & 11 & 23.4 & 8 & 26.7 & 32 & 33.7 \\
\hline Total & 18 & 100.0 & 47 & 100.0 & 30 & 100.0 & 95 & 100.0 \\
\hline \multicolumn{9}{|c|}{ Bahan baku } \\
\hline Beras & 5 & 27.8 & 3 & 6.4 & 1 & 3.3 & 9 & 9.5 \\
\hline Tepung sagu & 1 & 5.6 & 4 & 8.5 & 1 & 3.3 & 6 & 6.3 \\
\hline Tepung terigu & 10 & 55.6 & 21 & 44.7 & 0 & .0 & 31 & 32.6 \\
\hline Kentang & 0 & .0 & 2 & 4.3 & 0 & .0 & 2 & 2.1 \\
\hline Singkong & 0 & .0 & 2 & 4.3 & 0 & .0 & 2 & 2.1 \\
\hline Jagung & 0 & .0 & 1 & 2.1 & 0 & .0 & 1 & 1.1 \\
\hline $\begin{array}{l}\text { Kacang- } \\
\text { kacangan }\end{array}$ & 0 & .0 & 4 & 8.5 & 0 & .0 & 4 & 4.2 \\
\hline Sayuran & 1 & 5.6 & 0 & .0 & 0 & .0 & 1 & 1.1 \\
\hline Daging/ayam & 1 & 5.6 & 0 & .0 & 0 & .0 & 1 & 1.1 \\
\hline Susu & 0 & .0 & 0 & .0 & 6 & 20.0 & 6 & 6.3 \\
\hline Buah & 0 & .0 & 0 & .0 & 6 & 20.0 & 6 & 6.3 \\
\hline Lainnya & 0 & .0 & 10 & 21.3 & 16 & 53.3 & 26 & 27.4 \\
\hline Total & 18 & 100.0 & 47 & 100.0 & 30 & 100.0 & 95 & 100.0 \\
\hline
\end{tabular}

Tabel 2. Sebaran Siswa Berdasarkan Jumlah Jenis Makanan Jajanan

\begin{tabular}{|c|c|c|c|c|c|c|}
\hline \multirow{2}{*}{ Jumlah Jenis Jajanan/minggu } & \multicolumn{2}{|c|}{ Makanan Utama } & \multicolumn{2}{|c|}{ Makanan Ringan } & \multicolumn{2}{|c|}{ Minuman } \\
\hline & $\mathrm{n}$ & $\%$ & $\mathrm{n}$ & $\%$ & $\mathrm{n}$ & $\%$ \\
\hline$<2$ jenis & 8 & 16.0 & 0 & .0 & 0 & .0 \\
\hline 2-3 jenis & 25 & 50.0 & 0 & .0 & 11 & 22.0 \\
\hline 4- 5 jenis & 15 & 30.0 & 11 & 22.0 & 23 & 46.0 \\
\hline 6-7 jenis & 2 & 4.0 & 23 & 46.0 & 6 & 12.0 \\
\hline$>7$ jenis & 0 & .0 & 16 & 32.0 & 10 & 20.0 \\
\hline Total & 50 & 100.0 & 50 & 100.0 & 50 & 100.0 \\
\hline Rata-rata \pm SD & \multicolumn{2}{|c|}{$2.98 \pm 1.363$} & \multicolumn{2}{|c|}{$7.24 \pm 2.471$} & \multicolumn{2}{|c|}{$5.64 \pm 3.161$} \\
\hline
\end{tabular}

Tabel 3. Sebaran Siswa Berdasarkan Frekuensi Jajan

\begin{tabular}{|c|c|c|c|c|c|c|}
\hline \multirow[t]{2}{*}{ Frekuensi Jajan/minggu } & \multicolumn{2}{|c|}{ Makanan Utama } & \multicolumn{2}{|c|}{$\begin{array}{c}\text { Makanan } \\
\text { Ringan }\end{array}$} & \multicolumn{2}{|c|}{ Minuman } \\
\hline & $\mathrm{n}$ & $\%$ & $\mathrm{n}$ & $\%$ & $\mathrm{n}$ & $\%$ \\
\hline$<3$ kali & 8 & 16.0 & 0 & .0 & 0 & .0 \\
\hline 3-5 kali & 22 & 44.0 & 1 & 2.0 & 13 & 26.0 \\
\hline 6-8 kali & 9 & 18.0 & 8 & 16.0 & 15 & 30.0 \\
\hline 9-11 kali & 6 & 12.0 & 8 & 16.0 & 12 & 24.0 \\
\hline$>11$ kali & 5 & 10.0 & 33 & 66.0 & 10 & 20.0 \\
\hline Total & 50 & 100.0 & 50 & 100.0 & 50 & 100.0 \\
\hline Rata-rata \pm SD & & & 13.4 & 4.862 & & 5.699 \\
\hline
\end{tabular}


Bahan baku makanan jajanan diantaranya berasal dari beras, tepung terigu, tepung sagu, kentang, singkong, kacangkacangan, jagung, sayuran, daging/ayam, buah, susu, gula, dan lainnya. Sebesar $55.6 \%$ makanan utama/sepinggan merupakan olahan tepung terigu. Sebanyak $44.7 \%$ makanan camilan/panganan adalah olahan tepung terigu. Beberapa hal yang dapat menyebabkan banyaknya penggunaan olahan tepung terigu diantaranya relatif mudah diolah dalam variasi bentuk, warna, dan rasa; banyak disukai siswa; murah; dan banyak tersedia.

\section{Kebiasaan Jajan Siswa}

\section{Jumlah Jenis Makanan jajanan}

Jumlah jenis makanan jajanan adalah banyaknya jumlah dari masing-masing jenis makanan jajanan yang dibeli siswa di lingkungan SD selama satu minggu. Tabel 2 memperlihatkan bahwa separuh siswa $(50.0 \%)$ membeli makanan utama/sepinggan sebanyak 2-3 jenis per minggu. Sebanyak $46.0 \%$ siswa membeli makanan camilan/panganan 6-7 jenis per minggu. Sebesar 46.0\% siswa membeli minuman 4-5 jenis per minggu (Tabel 2 ).

\section{Frekuensi Jajan}

Frekuensi jajan siswa per hari disajikan pada Tabel 3. Sebanyak $44.0 \%$ siswa memiliki frekuensi jajan makanan utama/sepinggan 3-5 kali/minggu. Sebagian besar siswa $(66.0 \%)$ siswa memiliki frekuensi jajan makanan ringan/panganan $\geq 11$ kali/minggu. Sebesar 30.0\% siswa memiliki frekuensi jajan makanan jajanan jenis minuman (6-8 kali/minggu). Tingginya ferkuensi makanan jajanan jenis makanan camilan/panganan diapat disebabkan oleh banyak tersedianya jajanan jenis ini.

\section{Konsumsi, Kecukupan, dan Tingkat Kecukupan Energi dan Zat Gizi}

Konsumsi energi sehari siswa berkisar antara 585 - 2372 kkal/hari. Rata-rata konsumsi energi sebesar $1595 \mathrm{kkal} / \mathrm{hari}$. Tingkat kecukupan energi siswa rata-rata sebesar $87.0 \%$ (Tabel 4). Energi diperlukan untuk mempertahankan hidup, menunjang pertumbuhan dan melakukan aktivitas fisik. Pangan sumber energi yang banyak dikonsumsi contoh antara lain mie instant, roti, dan bubur ayam.

Adapun konsumsi protein sehari siswa berkisar antara $14.4-89.2 \mathrm{~g} /$ hari. Rata-rata konsumsi protein siswa sebesar $54 \mathrm{~g} / \mathrm{hari}$. Tingkat kecukupan protein siswa rata-rata sebesar $115.0 \%$ (Tabel 4).

Pangan sumber protein yang banyak dikonsumsi contoh antara lain ayam goreng, cumi goreng, ikan goreng, rendang, sate ayam, telur ayam, dan udang. Konsumsi lemak sehari siswa berkisar antara 14.6 - 82.9 g/hari. Berdasarkan Tabel 4, rata-rata konsumsi lemak sebesar $54 \mathrm{~g} /$ hari. Tingkat kecukupan lemak siswa rata-rata sebesar $132.0 \%$. Pangan sumber lemak yang banyak dikonsumsi contoh antara lain mie susu dan produk-produk turunannya seperti es krim dan yoghurt.

Berdasarkan Tabel 4, tingkat kecukupan energi siswa berada dalam kategori defisit tingkat berat (34.0\%) dan normal (34.0\%). Sebanyak 44.0\% siswa memiliki tingkat kecukupan protein dalam kategori kelebihan. Separuh siswa memiliki tingkat kecukupan lemak dalam kategori kelebihan (56.0\%). Hal ini dapat dikarenakan konsumsi baik makanan jajanan maupun bukan makanan jajanan siswa yang kaya sumber protein dan lemak. Umumnya siswa minum susu paling sedikit satu gelas sehari. Jenis susu yang banyak dikonsumsi adalah susu full cream yang mempunyai kandungan protein dan lemak yang tinggi.

Tabel 4. Rata-rata Konsumsi, Kecukupan, dan Tingkat Kecukupan Energi dan Zat Gizi Siswa

\begin{tabular}{lccc}
\hline \multicolumn{1}{c}{ Rata-rata sehari } & Konsumsi & Kecukupan & Tingkat Kecukupan $(\%)$ \\
\hline Energi (kkal) & 1595 & 1921 & 87.0 \\
Protein (g) & 52 & 47 & 115.0 \\
Lemak (g) & 54 & 43 & 132.0 \\
Zat Besi (mg) & 16 & 16 & 103.0 \\
Vitamin A (RE) & 874 & 596 & 148.0 \\
Vitamin C (mg) & 47 & 50 & 95.0 \\
\hline
\end{tabular}


Sebagian besar siswa (62.0\%) memiliki tingkat konsumsi zat besi yang cukup. Hal ini dapat dikarenakan tingginya konsumsi pangan sumber protein hewani yang banyak mengandung zat besi. Sebagian besar $(76.0 \%)$ tingkat konsumsi vitamin A siswa berada dalam kategori cukup (Tabel 18). Makanan sumber vitamin A diantaranya wortel, hati ayam, minyak goreng, dan lain-lain.

Tingkat kecukupan vitamin $\mathrm{C}$ sebagian besar siswa $(76.0 \%)$ berada pada kategori kurang (Tabel 18). Vitamin C banyak terdapat pada buah dan sayuran. Makanan jajanan di sekolah hanya sedikit yang merukanan pangan sumber buah dan sayuran. Selain ketersediaannya yang sedikit, buah dan sayur kurang diminati anak-anak untuk dikonsumsi.

\section{Kontribusi Makanan Jajanan Terhadap Konsumsi Sehari dan Tingkat Kecukupan Gizi}

Kontribusi makanan jajanan sebaiknya tidak dihilangkan dari konsumsi harian, karena memberikan sumbangan yang cukup berarti. Makanan jajanan juga dapat dijadikan salah satu alternatif pemenuhan sumber zat gizi yang kurang dari konsumsi hariannya. Sebaiknya makanan jajanan yang dikonsumsi menyumbangkan $10-20 \%$ energi atau sebesar 192-384 kkal. Berdasarkan Tabel 5, rata-rata konsumsi makanan jajanan siswa sudah melebihi $20 \%$ energi, yaitu sebesar $426 \mathrm{kkal}$. Makanan jajanan siswa memberikan kontribusi terhadap total konsumsi masing-masing sebesar $26.0 \%$ energi, $18.7 \%$ protein, $22.9 \%$ lemak, $20.0 \%$ zat besi, $19.1 \%$ vitamin A, dan 24.8 vitamin C (Tabel 5). Hal ini menguatkan hasil penelitian Ulya (2003) yang dilakukan pada salah satu sekolah dasar di Jakarta Timur menyebutkan bahwa kontribusi makanan jajanan terhadap konsumsi sehari siswa berkisar antara 10-20\%. Kontribusi makanan jajanan terhadap kecukupan gizi siswa masing masing sebesar $23.0 \%$ energi, $21.7 \%$ protein, $30.1 \%$ lemak, $19.5 \%$ zat besi, $24.1 \%$ vitamin A, dan $26.6 \%$ vitamin C (Tabel 5).

Kajian makanan jajanan di Afrika menyebutkan bahwa makanan jajanan memberikan kontribusi energi sepertiga dan sepertempat vitamin dan mineral dari konsumsi harian. Makanan jajanan yang dibeli anak umumnya mengenyangkan dan kaya akan energi dan lemak, namun sangat kurang zat gizi mikro (Bremmer et al. 1990; Pratap \& Booluck 2005; FAO 2007).
Faktor-faktor yang Berhubungan dengan Kebiasaan Jajan Siswa

Berdasarkan hasil uji korelasi Spearman, jenis kelamin dan umur tidak memiliki hubungan dengan kebiasaan jajan (jumlah jenis makanan jajanan dan frekuensi jajan). Karakteristik keluarga terdiri dari tingkat pendidikan orang tua, pekerjaan orang tua, pendapatan keluarga, dan besar keluarga. Hasil korelasi Spearman menunjukkan tidak terdapat hubungan antara karakteristik keluarga dengan kebiasaan jajan.

Korelasi Pearson digunakan untuk mengetahui hubungan antara alokasi uang saku untuk membeli makanan jajanan dan pengetahuan gizi siswa tentang makanan jajanan dengan kebiasaan jajan siswa (jumlah jenis jajanan dan frekuensi jajan). Hasil uji korelasi Pearson menunjukkan bahwa variabel yang mempunyai hubungan signifikan terhadap kebiasaan jajan adalah alokasi uang saku untuk membeli jajanan.

Tidak terdapat hubungan antara pengetahuan gizi tentang makanan jajanan dengan kebiasaan jajan siswa. Hal ini menguatkan hasil penelitian Ekeke dan Thomas (2007) di Wales menyebutkan bahwa tidak ada hubungan yang nyata antara pemilihan pangan anak dengan pengetahuan mereka tentang gizi seimbang. Meskipun anak-anak mengetahui bahwa mereka membutuhkan makanan yang sehat untuk pertumbuhan, kesehatan, dan pemenuhan zat gizi mereka, namun sangat sedikit pemahaman tentang fungsi zat gizi di dalam tubuh.

Hubungan Alokasi Uang Saku untuk Membeli Jajanan dengan Jumlah Jenis Makanan Jajanan

Siswa SD mengalokasikan uang sakunya untuk berbagai keperluan. Alokasi uang saku terbesar digunakan siswa untuk membeli jajanan. Terdapat hubungan yang positif dan signifikan $(p<0.01)$ antara alokasi uang saku untuk membeli jajanan dengan jumlah jenis makanan jajanan yang dibeli siswa. Artinya semakin besar alokasi uang saku untuk membeli jajanan maka jumlah jenis jajanan yang dibeli akan semakin besar pula. Berdasarkan Tabel 8, nilai koefisien korelasi Pearson jumlah jenis jajanan makanan utama/sepinggan;makanan camilan/panganan; dan minuman masing-masing sebesar $(r=0.51)$, $(r=0.63)$, dan $(r=0.61)$. 
Tabel 5. Rata-rata Kontribusi Makanan Jajanan terhadap Konsumsi Sehari dan Tingkat Kecukupan Gizi

\begin{tabular}{lcccccc}
\hline \multicolumn{1}{c}{ Makanan jajanan } & $\begin{array}{c}\text { Energi } \\
(\mathrm{kkal})\end{array}$ & $\begin{array}{c}\text { Protein } \\
(\mathrm{g})\end{array}$ & Lemak $(\mathrm{g})$ & $\begin{array}{c}\text { Besi } \\
(\mathrm{mg})\end{array}$ & $\begin{array}{c}\text { Vit. A } \\
(\mathrm{RE})\end{array}$ & $\begin{array}{c}\text { Vit. C } \\
(\mathrm{mg})\end{array}$ \\
\hline Konsumsi makanan jajanan & 426 & 9.9 & 12.5 & 3.1 & 144.0 & 12.9 \\
Kontribusi terhadap total konsumsi (\%) & 26 & 18.7 & 22.9 & 20.0 & 19.1 & 24.8 \\
Kontribusi terhadap kecukupan gizi (\%) & 23 & 21.7 & 30.1 & 19.5 & 24.1 & 26.6 \\
\hline
\end{tabular}

Tabel 6. Sebaran Siswa Berdasarkan Frekuensi Jajan dan Alokasi Uang Saku untuk Membeli Jajanan

\begin{tabular}{|c|c|c|c|c|c|c|c|c|}
\hline \multirow[t]{3}{*}{$\begin{array}{c}\text { Jumlah Jenis } \\
\text { (jenis/minggu) }\end{array}$} & \multicolumn{6}{|c|}{ Alokasi Uang Saku untuk Membeli Jajanan (\%) } & \multicolumn{2}{|c|}{ Total } \\
\hline & \multicolumn{2}{|c|}{$<45.6 \%$} & \multicolumn{2}{|c|}{$45.6-92.2 \%$} & \multicolumn{2}{|c|}{$>92.2 \%$} & & \\
\hline & $\mathrm{n}$ & $\%$ & $\mathrm{n}$ & $\%$ & $\mathrm{n}$ & $\%$ & $\mathrm{n}$ & $\%$ \\
\hline$<11$ & 0 & .0 & 2 & 4.0 & 0 & .0 & 2 & 4.0 \\
\hline $11-23$ & 7 & 14.0 & 22 & 44.0 & 12 & 24.0 & 41 & 82.0 \\
\hline$>23$ & 1 & 2.0 & 4 & 8.0 & 2 & 4.0 & 7 & 14.0 \\
\hline Total & 8 & 16.0 & 28 & 56.0 & 14 & 28.0 & 50 & 100.0 \\
\hline \multirow{3}{*}{$\begin{array}{l}\text { Frekuensi Jajan } \\
\text { (kali/minggu) }\end{array}$} & \multicolumn{6}{|c|}{ Alokasi Uang Saku untuk Membeli Jajanan (\%) } & \multirow{2}{*}{\multicolumn{2}{|c|}{ Total }} \\
\hline & \multicolumn{2}{|c|}{$<45.6 \%$} & \multicolumn{2}{|c|}{$45.6-92.2 \%$} & \multicolumn{2}{|c|}{$>92.2 \%$} & & \\
\hline & $\mathrm{n}$ & $\%$ & $\mathrm{n}$ & $\%$ & $\mathrm{n}$ & $\%$ & $\mathrm{n}$ & $\%$ \\
\hline$<19$ & 2 & 4.0 & 3 & 6.0 & 0 & 0.0 & 5 & 10.0 \\
\hline $19-41$ & 5 & 10.0 & 20 & 40.0 & 11 & 22.0 & 36 & 72.0 \\
\hline$>41$ & 1 & 2.0 & 5 & 10.0 & 3 & 6.0 & 9 & 18.0 \\
\hline Total & 8 & 16.0 & 28 & 56.0 & 14 & 28.0 & 50 & 100.0 \\
\hline
\end{tabular}

Berdasarkan nilai koefisien korelasinya makanan camilan/panganan dan minuman memiliki tingkat hubungan yang tinggi. Makanan utama/sepinggan memiliki tingkat hubungan sedang.

\section{Hubungan Alokasi Uang Saku untuk Membeli Jajanan dengan Frekuensi Jajan}

Frekuensi jajan juga memiliki hubungan yang positif dan signifikan $(p<0.01)$ dengan alokasi uang saku untuk membeli jajanan. Nilai korelasi Pearson frekuensi jajan makanan utama/sepinggan; makanan camilan/panganan; dan minuman masing-masing sebesar $(r=0.56),(r=0.73),(r=0.78)$. Berdasarkan nilai signifikansinya makanan camilan/panganan dan minuman memiliki tingkat hubungan yang tinggi. Sedangkan makanan utama/sepinggan memiliki tingkat hubungan sedang. Hal ini berarti semakin tinggi alokasi uang saku untuk membeli jajanan maka frekuensi yang dibeli akan semakin banyak (Tabel 6). Besar uang saku anak merupakan salah satu indikator sosial ekonomi keluarga. Semakin tinggi alokasi uang saku untuk membeli jajanan maka jumlah jenis jajanan yang dibeli akan semakin banyak.

\section{Faktor - Faktor yang Berpengaruh terhadap Kebiasaan Jajan Siswa Sekolah dasar}

Analisis regresi dilakukan untuk mengetahui faktor-faktor yang berpengaruh terhadap kebiasaan jajan siswa dengan variabel dependen yakni kebiasaan jajan (jumlah jenis makanan jajanan dan frekuensi jajan). Variabel independen adalah karakteristik contoh (umur, alokasi uang jajan, dan pengetahuan gizi), serta karakteristik keluarga (pendapatan orang tua dan besar keluarga).

\section{Faktor - Faktor yang Mempengaruhi Jumlah} Jenis Makanan Jajanan

Hasil penelitian menunjukkan bahwa variabel independen yang berpengaruh secara signifikan terhadap jumlah jenis makanan jajanan adalah alokasi uang saku untuk membeli jajanan $(p<0.01)$. Sebanyak $35.7 \%$ variabel dependen (jumlah jenis makanan jajanan) dijelaskan oleh variabel independennya (alokasi uang saku untuk membeli jajanan), dan 64.3\% dijelaskan oleh variabel lain diluar variabel yang digunakan. Persamaan regresi yang digunakan untuk mengetahui faktor-faktor yang mempengaruhi jumlah jenis jajanan adalah :

$$
\mathrm{Y}=3.074+0.088 \mathrm{X} 1+\mathrm{e}
$$

Keterangan :

$\mathrm{Y}=$ Jumlah jenis jajanan

$\mathrm{X} 1$ = Alokasi uang jajan (Rp)

Berdasarkan persamaan regresi, jika tidak ada kenaikan alokasi uang saku untuk membeli jajanan, maka jumlah jenis makanan jajanan yang dibeli akan mencapai 3.074. Setiap penambahan alokasi uang jajan sebesar Rp 1 akan menaikkan jumlahjenis makanan jajanan sebesar 0,088 jenis. 


\section{Faktor - Faktor yang Mempengaruhi Frekuensi Jajan}

Hasil penelitian menunjukkan bahwa variabel independen yang berpengaruh secara signifikan terhadap frekuensi jajan di kantin adalah alokasi uang jajan $(p<0.01)$. Sebanyak $36.2 \%$ variabel dependen (frekuensi jajan) dijelaskan oleh variabel independennya (alokasi uang saku untuk membeli jajanan), dan $63.8 \%$ dijelaskan oleh variabel lain diluar variabel yang digunakan.

Persamaan regresi yang digunakan untuk mengetahui faktor yang mempengaruhi frekuensi jajan di kantin adalah :

$$
\mathrm{Y}=4.012+0.091 \mathrm{X} 1+\mathrm{e}
$$

Keterangan :

$Y=$ Frekuensi jajan di kantin

$\mathrm{X} 1$ = Alokasi uang jajan (Rp)

Berdasarkan persamaan regresi, jika tidak ada kenaikan alokasi uang saku untuk membeli jajanan, maka frekuensi jajan akan mencapai 4.012. Setiap penambahan alokasi uang jajan sebesar Rp 1 akan menaikkan frekuensi jajan sebesar 0.091 kali.

\section{KESIMPULAN}

Kebiasaan jajan siswa sekolah dasar tidak perlu dihilangkan karena memberikan kontribusi yang berarti terhadap konsumsi sehari dan kecukupan gizi siswa. Kebiasaan jajan meliputi jumlah jenis makanan jajanan dan frekuensi jajanan. Sebanyak $50.0 \%$ siswa membeli makanan utama 2-3 jenis/minggu. Sebesar $46.0 \%$ siswa membeli makanan ringan 6-7 jenis/minggu, dan $46.0 \%$ siswa membeli minuman 4-5 jenis/minggu. Frekuensi jajan makanan utama siswa (3-5 kali/minggu) sebesar (44.0\%). Sebesar $66.0 \%$ siswa memiliki frekuensi jajan > $11 \mathrm{kali} /$ minggu, dan 30.0\% siswa memiliki frekuensi jajan minuman 6-8 kali/minggu.

Sebesar $34.0 \%$ siswa memiliki tingkat kecukupan energi dalam kategori defisit tingkat berat adan normal. Sedangkan tingkat kecukupan protein dan lemak berada dalam kategori kelebihan masing-masing sebesar (46.0\%) dan (56.0\%).

Sebagian besar siswa memiliki tingkat kecukupan zat besi $(62.0 \%)$ dan vitamin A (76.0\%) cukup. Sedangkan vitamin C berada pada kategori kurang (76.0\%). Rata-rata kontribusi makanan jajanan terhadap total konsumsi energi sebesar 26.0\%; protein (18.7\%); lemak (22.9\%), zat besi (20.0\%); vitamin A (19.1\%); dan vitamin C (24.8\%). Sedangkan rata-rata kontribusi makanan jajanan terhadap tingkat kecukupan gizi yaitu energi sebesar (23.0\%); protein (21.7\%); lemak (30.9\%), zat besi (19.5\%); vitamin A (24.1\%); dan vitamin C (26.6\%).

Berdasarkan hasil uji korelasi Pearson, terdapat hubungan yang positif dan signifikan $(p<0.01)$ antara alokasi uang saku dengan kebiasaan jajan. Variabel independen yang berpengaruh secara signifikan terhadap jumlah jenis makanan jajanan dan frekuensi jajan adalah alokasi uang saku untuk membeli jajanan.

\section{DAFTAR PUSTAKA}

Almatsier S. 2004. Penuntun Diet. Gramedia Pustaka Utama, Jakarta.

Bremner B, Langenhoven ML, Swanepoel AS, Steyn M. 1990. The snacking habits of white preschool children. South African Med Journal, 78, 472-5.

[Depkes] Departemen Kesehatan. 2005. Panduan 13 Pesan Dasar Gizi Seimbang. Depkes, Jakarta.

Ekeke JTH, Thomas M. 2007. Primary children's choice of food and their knowledge of balanced diet and healthy eating. British Food Journal, 109, 457-68.

Khomsan A. 2000. Teknik Pengukuran Pengetahuan Gizi. Jurusan Gizi Masyarakat dan Sumberdaya Keluarga Fakultas Pertanian Institut Pertanian Bogor, Bogor.

Pratap BO, Booluck BJH. 2005. Children's consumption of snack at school in Mauritius. Nutrition and Food Science, 35,15-19.

Suhardjo. 1989. Sosio Budaya Gizi. Departemen Pendidikan dan Kebudayaan, Direktorat Jendral Pendidikan Tinggi Pusat Antar Universitas Pangan dan Gizi, Institut Pertanian Bogor, Bogor.

Ulya N. 2003. Analisis Deskriptif Pola Jajan dan Kontribusi Zat Gizi Makanan Jajanan Terhadap Konsumsi Sehari dan Status Gizi Anak Kelas IV, V, dan VI SD Negeri Cawang 05 Pagi Jakarta Timur Tahun 2003. Skripsi Sarjana Kesehatan Masyarakat, Fakultas Kesehatan Masyarakat, Universitas Indonesia, Depok. 